\title{
THE PHENOMENON OF THE INTERNET MEMES AS A MANIFESTATION OF COMMUNICATION OF VISUAL SOCIETY - RESEARCH OF THE MOST POPULAR AND THE MOST COMMON TYPES
}

\begin{abstract}
The society of the 21st century is a society of visual communication that mainly takes place on the Internet. Of the many forms of visual expression on the Internet among the most widespread and most expressive are the Memes. Internet Memes are the most common video and photo content on the Internet, which convey or send a specific (often humorous) message, whose codes and meanings are well-grounded in the global culture. The aim of work is to define, explain, historical displays, classify and highlight the features of the internet memes, as well as to detect which type of memes are most often and/or the most popular and what are its characteristics. The basic hypothesis claims: The most common types of Internet memes appear in the form of photographs, they have humorous characteristics in a function of entertainment and they are the most popular because they are parodying the most popular series and movies form. The study was conducted by quantitative and qualitative analysis of the 150 most popular Memes in the period from 22 to 24 of May 2019, on the site 9gag.com. The collected data are classified and compared by statistical analysis in the program called the SPSS 20.0. The results indicate that the most numerous among the popular memes are those in the form of photos or images, that are mostly comically character and in the function of entertainment, and the most popular among them are dealing with phenomena and epiphanies common to all people. Also is noticed the increasing popularity of memes in the form of moving pictures and in a neutral context in relation to those who are the most numerous (in the form of pictures or photos and comedic contexts). The only common and invariant feature and the widest number of memes, as well as those who are the most popular, is that they are in the function of entertainment.
\end{abstract}

Key words: Internet Memes, images, visual society, video, communication

\footnotetext{
${ }^{1}$ Received August 2019 / Accepted November 2019

${ }^{2}$ E-mail: ilija.milosavljevic992@gmail.com

${ }^{3}$ The paper was prepared as part of the project Tradition, Modernization and National Identity in Serbia and the Balkans in the Process of European Integration (179074), funded by the Ministry of Education, Science and Technological Development of the Republic of Serbia, and implemented by the Center for Sociological Research at the Faculty of Philosophy in Niš.
} 


\section{Introduction}

Visual observation of the world by people represents the basic form of information and orientation in the environment. As many as $83 \%$ of the information people get over this sense (Oklahoma State University, 2016). Many great discoveries, and probably the very development of humans in civilized beings, would not have been possible without the orienting with the help of observation. The very primary communication, for which some theorists (Luhman, 1975: 198) consider that preceded in the development of the social system, was based largely on visual contact between individuals.

Human society, historically watching, the most considerable period of its existence relied on direct information through observation and watching (Baldwin, Roberts, 2006; Sturken, Cartwright, 2001). With the arrival of the letter, written books and sometimes later with the emergence of the Gutenberg printing press and radio, society less and less relied on observation for the sake of information. Visual observations are part of the reading, but in contrast to simple observing is the highly defined, clear codified, oriented and organized, while with the appearance of the radio, visual effects of man are completely put aside. However, the popularization of new media such as movies, television and finally the Internet, informing, communication and learning by observing the image again becomes the dominant feature of modern society. The phenomenon of change in people's habits and ways in which the society operates is a consequence of the development of new technologies and ways of communicating that Canadian theorist Marshall McLuhan (Marshall McLuhan, 2012: 23-25) has called technological determinism. He predicted in 1968 the end of the culture of literacy and a return of visual culture due to the appearance of television that has marginalized its predecessors such as radio and print. This tendency also proved to be more accurate in the age of the Internet, which, although in itself incorporates all types of media and multimedia, can be defined as a medium of sight in the first place. Forms of visual communications are manifold on it, such as viewing video content on sites like YouTube and Vimeo, communication via emoji and gifs, scrolling through the photos on social networks... Moreover, dominance visual over text elements can be observed in the development of social networks. Thus, on the social network Facebook ratio of text and images from year to year is more and more on the side of the image (through photos, videos, gifs, emojis, stickers) and the best example of this tendency is undoubtedly Instagram, which is rising in popularity among users and in its usage in media sphere (Obradović, Milosavljević, Vujović, 2017) while is based exclusively on exchange and publication of video and photo content.

In an emergence of visual forms of communication on the Internet, are especially prominent Memes that appear most often in the form of videos or photos. They can transmit complicated messages that often have denotative and connotative meaning are widely accepted, because of its humorous content. Therefore they become one of the most widely used forms of online visual communication in almost 
all spheres of society. Memes are primarily humorous caricatures and imitations, but as visual representation of humor is one of the most popular aspects of internet communication, they have become trendy in the spheres of information, marketing, politics, and even some sort of art. The aim is to analyze which forms, types and functions of the Memes are the most popular and the most common on the Internet and what are the characteristics that make them popular.

\section{The definition, characteristics and classification of the memes}

Term "MEME" was introduced by Richard Dawkins, indicating the different types of information (ideas, habits, figures) that spread, multiply and change in the environment of human culture (Dawkins, 2006). Because he was an evolutionist he actually tried with this term to explain his view that ideas evolve in the society under its influence, that they are changing and getting a new meanings, primarily on the concepts of imitation and copying. Carlos Diaz adds that Memes are behaving similarly to viruses and that they fight to survive by "infecting" brain, moving from one to the other man and extending through human society (Diaz, 2013: 85).

Internet Memes are a recent phenomenon and refer to the most popular often funny concepts that are transmitted online. Linda Börzsei believes that the first internet Memes were emoticons that were created by combining different characters and letters (such as “:-)" - smiling emoticon) (Börzsei, 2013). Memes may be in the form of text, news, but they are usually video, photo or animation content (Šešum, 2011: 108). A characteristic of these types is that they are presented in combination of image content (which dominates) and the textual content that serves as a clarification of ideas of a meme. Pictorial contents are usually "borrowed" from other forms of culture, such as series, movies or news, and as such are constantly appearing by parodying of the same. The textual part is variable and it determines the connotative meaning of meme. Often individual memes overcome the popularity of works that imitate, and how much can they be popular illustrates the news that appeared in many prominent portals (such as the $\mathrm{BBC}^{4}, \mathrm{CNN}^{5}$ ) that is "grumpy cat", whose photo has become one of the most famous Memes in the world, died.

Based on the definition and categorization of different authors (Diaz, 2013; Tech, 2012; Shifman, 2014: 41-42), it is possible to single out a few key features of internet Memes:

- Imitation - Memes represent a copy of the original that it imitates but also surpasses

- Cultural and social conditionality - The original is a part of the culture, it is well known, and the society serves as a transmitter and creator of the meaning of a meme

- Specificity and visibility - Regardless of the original, memes themselves eventually start being recognized as a phenomenon

\footnotetext{
${ }^{4}$ https://www.bbc.com/news/world-us-canada-48308638 (accesed 18/05/2019)

${ }^{5}$ https://edition.cnn.com/2019/05/17/celebrities/grumpy-cat-dead-intl-scli/index.html (accessed 05/18/2019)
} 
- Humor and satire - They parody of the original, or with the original work served as the basis of his spirituality, changing the meanings.

- Simplicity - Wit and visibility are possible thanks to the simple structure of the memes that almost every member of society and culture can observe. Actually, it is simplicity, besides humor and visuality, which is one of the main reasons for the popularity of this form of social visuality.

- High compactness to the meanings - The simplicity of expression of the meme carries many different meanings, as denotative, so and connotative

- Combination of visual and textual - The ambiguity of the Memes consequence is often the fact that the memes are consist of the visual part (which is generally known, derives from the culture and serves as a message, context, implications) and textual (which often gives direct meaning)

All of these features (except the last) are common to all types of memes on the Internet. It would be wrong to consider that the memes appear only as a video and photo formats. They can be text-only, can mimic the news, and there are audio memes. However, the most widespread are picture and video memes. In terms of form, Milner (Milner, 2012) differ as much as 13 types of photographic memes, according to that whether the images are processed, which is divided into those that contain one (6 sub-types) or more images ( 2 subtypes), or were unprocessed (5 subtypes). According to the era in which they occur may be divided into "classic" (from 2007 to 2013) and "dank" (of 2013) and they differ because dank memes are more complex, higher quality and more diverse. If the main criteria is the way that memes access and present content from which they arise, or context or character they can be comical, critical, erotic, artistic or simply neutral, relatively informative.

Because Internet users create them in the online sphere, Memes often do not have a clearly defined function, but goal of their releasing can be defined, in addition to entertainment, as well as the expression of opinion and the promotion of authors who made them. Many sites which specialize in the creation, presentation and distribution of the memes have a system of ranking the popularity of the publication, as well as space for comments below each of them. The authors on these sites usually compete for space, quality assurance of their raciness or attitude that is expressed with the meme (Shifmann, 2014: 66-67). However, because they are both very popular and have the power to indicate certain phenomena, ideas and advances, memes are instrumentalized in various spheres of society, so their functions can be varied.

\section{The function of memes}

One of the ways in which they can be classified is according to their functions. Thus classified, they reflect the intentions of its creators. Humor is one of their essential characteristic and functions, but often constitutes an only feature of a meme, while the goal of the message that is transmitted can have a different meaning. Simply, because of its amusing and straightforward form, memes can serve 
as a medium and visual communication tool for fulfilling various objectives, so it is not uncommon to find memes in the propaganda and political communication.

\subsection{Function of entertainment}

Certainly, the most crucial function of memes stems precisely from their nature - the function of entertainment. This type of visual communication functions accords to the same principles as the Internet in general and all the mass media today, and those principles imply, according to analysts mass media the past 50 years, minimizing complexity and maximizing of entertainment (Vreg 1991:198-199; Juza 2013:5). Thanks to its form, they are ideally suited for the needs of free time of each member of society. Sometimes meme may have more features, but almost always one can be taken as dominant.

However, it is wrong to consider that the form itself is what defines entertainment of memes as such, because that every meme in its form is funny, this would mean that all of them were by function automatically classified into this category. In order by function for a meme to be designate as fun, it must transmit and contain meanings and messages that are exclusively, or at least in the highest degree, just a function of entertainment. In other words, the intention of the author of memes is, first and foremost, to joke and entertain those who observe his work. Such memes do not have an intentional hidden message that can be found in political advertising memes (Huntington, 2017:7). That what they do originates from the fundamental nature of memes, to humorously and satirically represent the original that arises from the culture of the society. So, all that memes which parody and in a humorous way represent elements of culture such as series, movies, artistic works, social events and other cultural and social phenomena, and do not have hidden and secondary intention, could be classified as entertainment memes.

It should be noted that, as is usually dealing with current developments in the global society, they necessarily carry with them and certain information and news for those who „read“ them.

\subsection{The Function of informing}

When informative or cognitive dimension of meme exceeds its entertainment function they can be defined as informative ones. Susan Blackmore says that one of the main characteristics in analyses of the of memes is observer subjectivity (Blackmore, 1999:7). It is therefore justified to doubt the possibility of determining the exact function of a meme. What is for the one subject news and information, for the other may be already known, and for him it will the primary operate in a function of entertainment. However, instead of observing the subject, the function of a meme can be much better learned by observing the intention of the authors of a meme and the form of a meme himself.

When the author gives an advantage in its meme to an expression of humor, parody, criticism or other types of posture on a phenomenon in society, it is assumed that the audience already knows about the phenomenon. On the other hand, when 
the emphasis is placed in the structure of meme on the phenomenon himself, more precisely to visual and text pointing to the existence of certain phenomena, then it is certainly the intention of the author to inform (Börzsei, 2013:21). For example, when the creator makes a meme which parodies or humorously represents a global popular television series, "The Game of Thrones", as shown in picture 1, it is assumed that the context of humor is commonly known. In contrast, when indicating their meme on a series "Altered Carbon" and news that there will be a second season and that lead role will play Anthony Maki (picture 2), its intention is to inform the audience about the innovations in this series. The informative memes themselves, in relation to humorous contain less humor, and their informativeness and clarity are much higher. There is no expressed secondary meanings and allusions as in entertaining memes, which makes them clearly different from them.
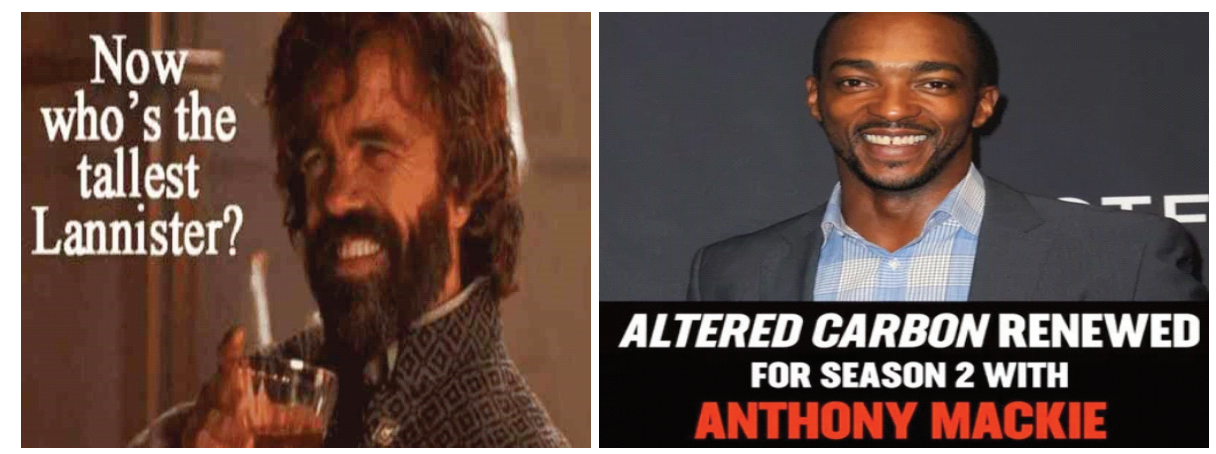

Picture 1 (left): Funny meme of the popular series "Game of Thrones"

Picture 2 (right): Informative meme about the series "Altered carbon"

Informativity of memes is possible because of their wit, and expressed visual character that corresponds to the visual communication society of the 21st century. Also, through them can be manifested the phenomenon of citizen journalism, which is also characteristic of the Internet society (Šarenac Radovanovic, 2012). Memes are simple to create, quick, decentralized, manufactured by citizens and have the ability to rapidly become popular $\left(\right.$ viral $\left.^{6}\right)$, which makes them a powerful instrument of citizen journalism. However, all these features do not need to be used only by ordinary citizens, and not only for the purpose of entertainment and information.

\subsection{Function of advertising}

The popularity of memes and their ability to humorously convey messages have contributed to the fact that certain interest groups have begun to use them in specific ways. In the first place, these are companies that have seen memes as cheap and effective means of advertising. What makes memes suitable for advertising in

\footnotetext{
${ }^{6}$ A closer term to explain the phenomenon of content that is spreading over the Internet like a huge speedster like a virus
} 
the first place is that they are very similar to advertising posters in its content and concept. However, their power is higher because on the Internet is possible to answer to every meme, unlike the poster, so, according to Baeta Bury, memes in advertising actually represent a kind of dialogue between the company and the consumer (Bury, 2016:34). These types of characterized memes, often well hidden, highlight the quality of a product or company or criticism (of a rival) in combination with humor. This feature and the increasing use of memes for this purpose, has drawn the attention of theorists of new media. Some of them, define the characteristics which memes must have to be successful in its intent, such as:

- Fertility - duplication of the same meme in different places on the Internet

- Simplicity - straightforward and short memes are faster spreading (which is the result of fragmented attention of visual society)

- Evoking primary instincts - memes which show fear, happiness or food are mainly internalized by the viewer

- Originality - The more meme is original the greater attention is gets (Murray et al. 2014: 340-344)

In defining and success of meme in commercial a significant role, in addition to pictures, plays a text. Text is the one that gives specific meaning, while the figure serves as a humorous context with secondary implications. This is a good example of memes that use the same picture, but with a different text, is a picture used by CocaCola and Pepsi in advertising.

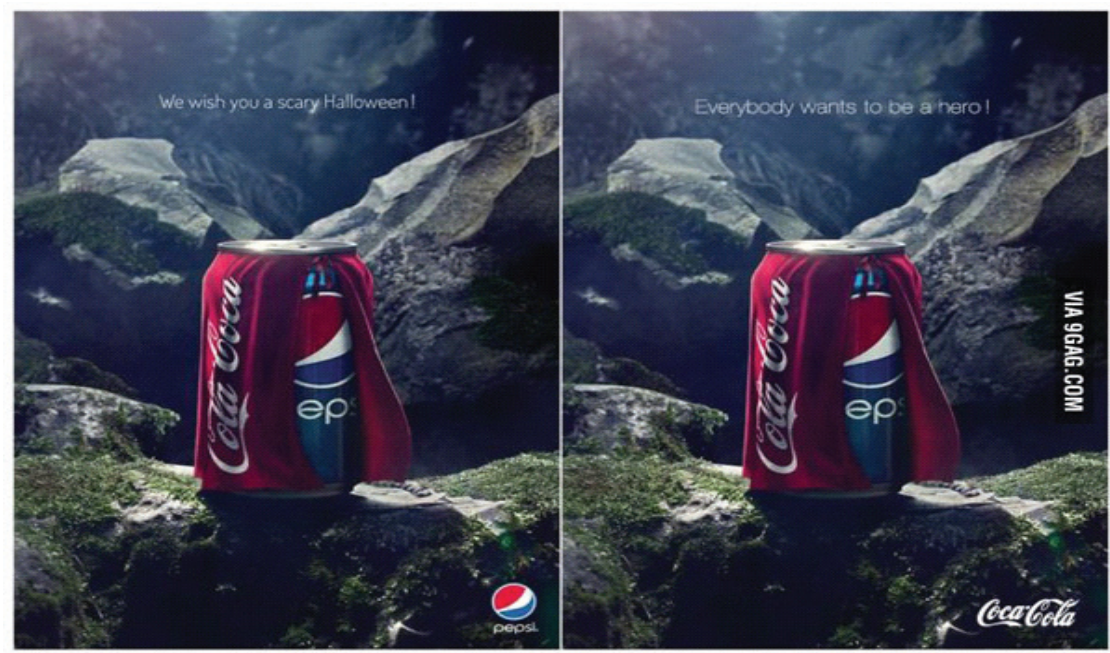

Original ad

Picture 3: The advertising memes of Pepsi and Coca-Cola with the same image and the different text

In Picture 3 are presented two memes that use the same image, in which the tin of Pepsi cola is wrapped in a garment which represents the Coca-Cola. When the company Pepsi in its advertising meme used this photograph they used the phrase 
"We wish you a scary Halloween" alluding to the fact that Coca-Cola is a scary mask, while Coca-Cola used this photo with comment "Everybody wants to be a hero", referring that it is a desire of Pepsi company is to become Coca-Cola, which is considered a hero.

Entire teams of experts take care about all these details, and creativity in creating meaning advertising memes. This kind of advertising can be handy and wellaccepted in society, because it contains all the features of content that want a visual society of the 21 st century. That is why it is not just commercial marketing agencies that have seen the power of this form.

\subsection{Memes in politics}

Using memes in political visual communication can be viewed from two perspectives. On the one hand, this form of expression is used, similar to traditional advertising, for the sake of promoting political figures and ideas. On the other hand, there are significant numbers of memes that are created by Internet users, which humorously or critically express their attitudes towards political phenomena, ideas and figures.

A meme can become a symbol of criticism or glorification of a particular political movement or figure. Anushka Kulkarni believes that modern memes are used as an active tool of political propaganda. She states that in every political campaign there are paid bloggers and internet users who have the task that trough to memes and visual humor define internet content to the interests of the party that they were hired (Kulkarni, 2017: 14). This kind of activity is considered to be a legitimate campaign on social networks, and its popularity shows the character of the society and the role of memes in it. Some authors state that memes can become a means of official political communication and to some extent this form of internet communication can be assigned a reversal role (picture 4) in the 2016 elections in the United States between Hillary Clinton and Donald Trump (Olsen, 2018; Piñeiro -Otero, MartínezRolán, 2016).

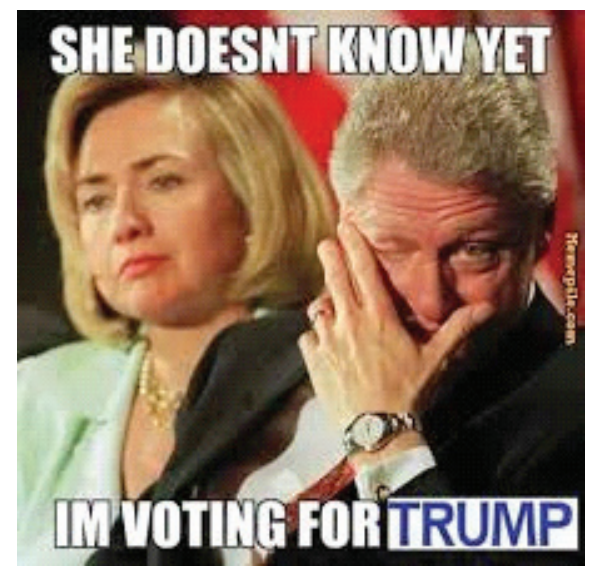

Picture 4: Example of meme with a political function 
However, a more frequent and more interesting visual phenomenon of online political communication is the use of memes by the Internet public in criticizing politics. This type of communication is due to its decentralized, while attractive nature very suitable for the distribution and dissemination of political views in the public sphere of the Internet. Most often, it is about parodying and shifting the context of a statement or position in which a political professional finds himself or her to look funny and frivolous (Chagas, Freire, Rios, Magalhães, 2019). This approach to politics is also an expression of his own stance as an anonymous individual and it creates the sense of participation (Plevriti, 2014: 41).

Political memes can often be similar to those whose function is purely entertainment, however, any political connotations or references, either in the text or visual part of the meme, clearly classifies them into a political category. The origin of the political meme, respecting the determination of the author and his intentions, it is often very difficult to determine, therefore the division on the political memes as a means of propaganda or act of political criticism and participation in practice almost impossible (Ross, Rivers, 2017). These two types of memes are almost always, according to their functions, defined only as political.

\section{The subject, the goal and the hypothesis of research}

The subject of research is the 150 most popular Internet memes by ranking from the internet site 9gag.com. They have been analyzed through the categories of form, character, function and popularity.

The primary aim of the research is to determine the most common and popular types of internet Memes by categories of form, character and function. Also, the aim is the analysis of the five most popular by the number of positive evaluations on the site 9.gag.com - determine their specificity and similarities which make them the most popular.

The research goal is to determine if the most common types of Internet Memes appear in the form of photos, have comic character in the function of entertainment, and if they are most popular because they parody popular series and film forms.

Due to this goal, following hypotheses are defined:

1. The most common form of Internet meme is a photo meme

2. The most common character of the Internet meme is a comic character

3. The most common function of the internet meme is entertainment function

4. The most popular memes parody popular series and movies form

\subsection{The Method}

For the study it is used qualitative and quantitative content analysis, as well as the descriptive and comparative statistical method. To check forms of a meme was used qualitative content analysis method, memes are classified as "photo", "gif", "video" and "other". For the analysis of the character is used meme qualitative analysis of 
content, and memes were analyzed according to the categories of "comical", "critical", "artistical" "erotic", and "neutral".

When analyzing the constructs of a meme was used qualitative content analysis, and according to this dimension memes were sorted as "entertainment", "informative", "advertising" and "political", according to the criteria of the theoretical part of the work. In the analysis of the characteristics of the most popular memes which were determined as the most popular by the number of positive criteria on the site on the day of the visit, it was used a qualitative analysis of the content, comparative method, and the synthesis as a method with the aid of which have been observed and isolated common features that can contribute to the popularity. All data were analyzed by the program SPSS 20.0 for statistics, in order to determine in the most accurate way the most present form, character and function, and by statistical comparison of these results verify all four hypotheses.

Memes were selected for analysis by popularity on the site called 9.gag.com, because this site is the one of the most popular, and the most upgradeable. It was analyzed the 50 most popular and recent Memes every day at noon in the period from 22 to 24 of May 2019, therefore there are 150 analyzed memes in total.

\section{Interpretation of the results and discussion}

In the framework of research has been analyzed 150 memes on the site 9gag. com over three days. After collecting all the relevant data about each individual meme through 4 categories: form, character, function and number of positive reviews, these data was analyzed by descriptive and comparative statistics. After that has been allocated five's most popular according to the number of positive customer ratings, which in the second part of interpretation results is shown by the method of comparative content analysis.

\subsection{Classification of the most popular forms, character and function of memes}

In relation to the form of memes statistical analysis shows that the greatest number of 150 memes analyzed is presented in the form of a processed or unprocessed photo or image, in particular $49.3 \%$, or 74 memes. As shown in Chart 1, on the second place by frequencies are gif memes, which makes $34 \%$ or 51 , and on the third are memes in the form of videos ( $12.7 \%$ or 19$)$. Under the category of "others" there were 6 memes $(4 \%)$ and they were in the form of text or internet correspondence. 


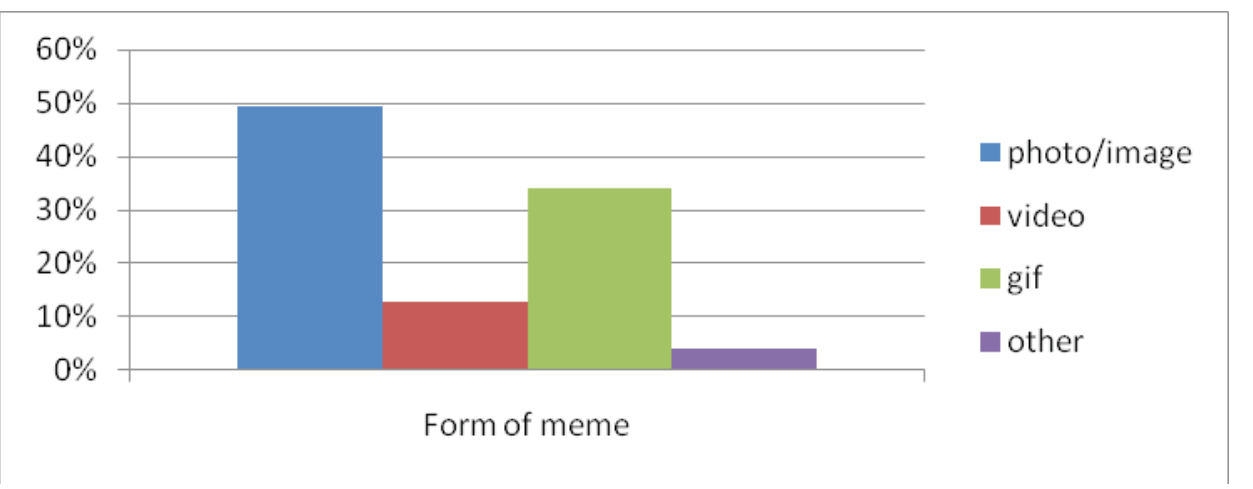

Chart 1. Percentage display division of memes analyzed according to a form

Given these data it can be concluded that the first hypothesis, which argues that the most common form of an internet meme is a picture, is confirmed. The most likely reason for this is the fact that this is the easiest way to make this form but also view it, and best meets the criteria of a good and fast meme in the society of internet visuality. It should be mentioned a large percentage of gif memes, which are shorter, simpler and compressed than video clips, and on the other hand have a higher information capacity of photo memes, so it can be expected that in the future, with the development of technology, they assume the role of the most common forms.

When it comes to character, regarding the way in which content is presented, in an analysis of 150 memes it was observed that the highest percentage of them have comical character, as much as $56 \%$ or 84 memes. On Chart 2 it can be seen that it is in second place by the number is neutral character of memes with $22.7 \%$, while the critical (8.7\%), erotic (7.3\%) and artistical (5.3\%) is significantly less.

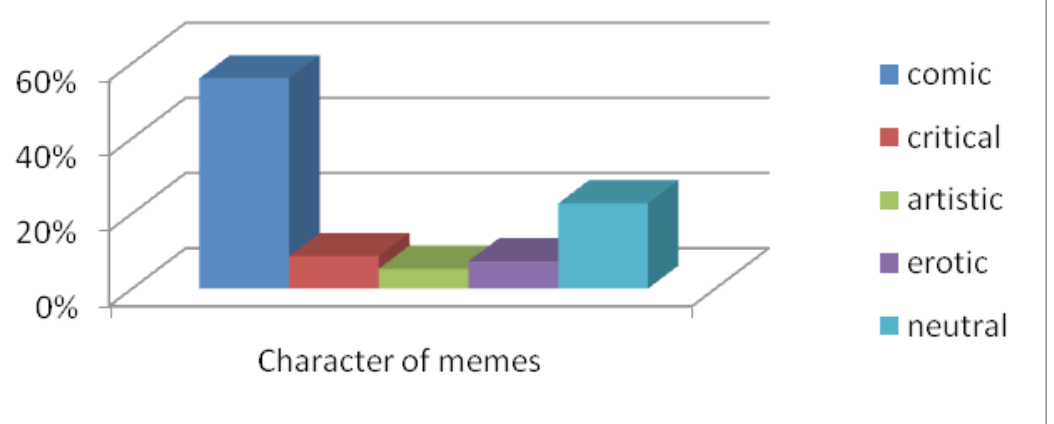

Chart 2. The types of analyzed memes according to the character

Thus, from the presented results it can be established that the most popular character of memes is comical, and that second hypothesis, which assumes the most common character of the internet meme comical character is confirmed. The nature of meme by itself is funny, and humor is the main goal, and it may be surprising that the percentage of comedic memes not greater than $56 \%$. However, as the fun is wider 
term than humor, other forms of communication of memes find their space on the site 9gag.com which is primarily designed for entertainment. Many neutral memes, are representing interesting phenomena such as technology innovation, interesting people, and locations that are not inherently humorous, but attract the interest and approval of the users of the site. The fact that critical, and especially erotic and artistic observed in much smaller percentage points to little power of memes to present such contents, and that there are other types of expression in the visual communication on the Internet, that more accurately present the message of this type.

In the division by the function it was observed domination of memes which aim was entertainment and in this group were found 101 memes or $67.3 \%$ of the total analyzed content (chart 3). Memes created in order to inform make 20.7\% (31 memes), those that are having the function of advertising only $2 \%$, or just 3 memes, and those which are defined as a politically occupying 10\% (15 memes) of the analyzed contents. Thus, a third hypothesis, which assumes that the most common feature of the internet memes is a feature of entertainment, is confirmed.

\section{Function of memes}

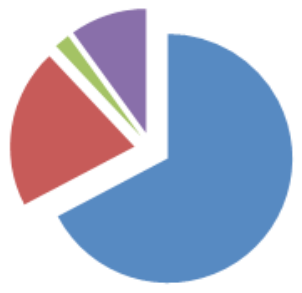

untertainment

informativity

advertisment

politics

Chart 3. Percentage display of memes by function

The greatest number of popular memes was created and is highly rated by users, primarily because they serve as pure entertainment. A certain percentage of memes has an informative function, which indicates that such visual content has the ability to communicate and transmit messages, apropos, via them it can be learned something. Advertising memes observed in the analysis are oriented to pointing out the positive things which had been done by individual companies, and thus in that way promote them. However, because there are very few of them, it can be concluded that this form is not as represented, at least not on the site 9gag, which is primarily designed for entertainment. This does not mean that memes with this function are not created on this site, but it shows that it is necessary, and very difficult to codify specific visual information into the ad, so that people do not recognize propaganda ideas of creators and their negative assessments prevent its spreading. Simple, here also it turned out that the best advertisement disguised and contextualized (Hackley, 2007). Political memes were in appeared in all the 15 cases as the parodying and satirizing of a certain politician. In most cases the subject of satire and criticism was the president of America Donald Trump and Theresa May, the Prime Minister of 
Great Britain and her policy Brexit. This is understandable if it is taken into account the research of Jelena Šešum which shows that nearly $68 \%$ of total views of Memes on the Internet come from the United States and Great Britain (Šešum, 2011:113). Thus, visual communication of memes is more characteristic for the West. There is no classical political propaganda, as it turned out also in the case of an advertisement; because users refuse and give negative ratings therefore do not allow that such memes come out on a main page.

In comparative statistical analysis of the form and character there were not observed greater regularity except that each form was mostly used in the comical context (photo 62.16\%; video 57.9\%; gif 47.05\%, the other 50\%), and that textual memes are not used in critical, artistic or erotic context. Also, it is observed that in the neutral, that is, in informative context most commonly used are gifs (52.94\%). As for the relationship between the form and function (Table 1), it is observed that for the politics in $66 \%$ of cases are used pictures and images, and in $100 \%$ of cases when it comes to the function of advertisement, while textual and other forms always are used for entertainment

\begin{tabular}{|c|c|c|c|c|c|c|}
\hline \multicolumn{7}{|c|}{ Table 1: Comparison of function and form } \\
\hline & & \multicolumn{4}{|c|}{ Form } & \multirow{2}{*}{ In total } \\
\hline & & Picture/image & Video & Gif & Other & \\
\hline \multirow{4}{*}{ Function } & Entertainment & 49 & 11 & 35 & 6 & 101 \\
\hline & Informational & 12 & 6 & 13 & 0 & 31 \\
\hline & Advertisement & 3 & 0 & 0 & 0 & 3 \\
\hline & Politics & 10 & 2 & 3 & 0 & 15 \\
\hline \multicolumn{2}{|c|}{ In total } & 74 & 19 & 51 & 6 & 150 \\
\hline
\end{tabular}

In the case of the comparison of the character and function (Table 2) it was shown that neutral memes are in extent in informative function, and that in commercial are used as humorous or critical. Thus it can be concluded that the advertising memes formed in such a way that funny and visually show their product or critically attack competition. Also, because there are $85.71 \%$ of comedic in the function of entertainment, it is clear that humor of memes, at least on the site 9gag.com, is not instrumentalized mainly for other purposes and that the users in that case do not support such a content.

\begin{tabular}{|c|c|c|c|c|c|c|c|}
\hline \multicolumn{8}{|c|}{ Table 2: Comparison of function and character } \\
\hline & & \multicolumn{5}{|c|}{ Character } & \multirow{2}{*}{ In total } \\
\hline & & Comical & Critical & Artistic & Erotic & Neutral & \\
\hline \multirow{4}{*}{ Function } & Entertainment & 72 & 5 & 4 & 10 & 10 & 101 \\
\hline & Informational & 4 & 2 & 4 & 1 & 20 & 31 \\
\hline & Commercial & 2 & 1 & 0 & 0 & 0 & 3 \\
\hline & Politics & 6 & 5 & 0 & 0 & 4 & 15 \\
\hline \multicolumn{2}{|c|}{ In total } & 84 & 13 & 8 & 11 & 34 & 150 \\
\hline
\end{tabular}




\subsection{Content analysis of the most popular five Memes}

Based on the number of positive reviews that users are left to each meme, there were singled out 5 the most popular. The highest number of positive ratings had a meme with 10453 ratings, while the lowest positive score of all analyzed memes had a meme with only 420 . So, for the meme to get on the list of the best on the site 9gag. com, more than 400 users must consider it as quality. An average score of positive memes analyzed on the basis of the mid arithmetic is 3440.02 .

Meme with the most positive score (10453) on the day of analysis is a meme in gif ${ }^{7}$ format, neutral character, informative/entertainment functions, but the informative one is dominant. This meme titled „This is how to stop bullying ${ }^{8 *}$ shows a boy who is opposed to the other boy who was bullying him. The popularity of this meme stemmed from the fact that the situation of bullying is very common and problematic issue and almost every user met sometimes in life with that situation. Also, gif indicates one of the opportunities to counter this phenomenon and actualizes this omnipresent social problem throughout the world. It can be concluded that the most popular meme is not the one who is the funniest, but one that is culturally the most widespread and the most understandable.

Another meme on the list of the most popular according to the analysis is also a gif, neutral character, with entertainment features with 10355 positive scores. It is meme called "Expecting mother getting an ultrasound ${ }^{\text {9" }}$ that displays a cat carrying the offspring and which was brought to the veterinarian on ultrasound. On this meme it can be seen a display of ultrasound on which cubs are shown. The meme is high on the top of popularity, primarily because of its bizarreness. Pregnancy, ultrasound and cats are also common phenomena of the culture around the world, but combinations of any of these terms are unusual and attract attention.

The third meme according to the norm of popularity with 10,177 positive ratings is also gif with neutral character and an entertaining feature called "Put this one in your pocket and go to be baptized ${ }^{10 "}$. At this meme was showed the black substance, which was standing in the palm of a person and that is placed in a tub full of water. After this act, the water turned in black color and bubbles were beginning to emerge out of the bladder. This meme was acclaimed for his humorous implications of that if in the act of baptism a person with this substance in their pockets sank into the water, there would be a very unusual situation, and possibly the comic reactions of those present. Again, it comes to the known form of a culture, such as a baptism, which is placed in the invert context in a creative way, it represents the reason for comical and the popularity of the meme.

The only meme in the form of video in the first five is meme titled "Still DRE $\mathrm{ft}$ mashup Theresa May ${ }^{11^{1 "}}$ which is with the 9688 positive ratings on fourth place by

\footnotetext{
${ }^{7}$ As each of the five most popular memes are in video or GIF format, it is not possible to display them in the work, so the links on which they can be vieved are in footnotes

${ }^{8}$ https://9gag.com/gag/arG03wV (accessed on 24/05/2019)

${ }^{9}$ https://9gag.com/gag/aVY8o4M (accessed on 24/05/2019)

${ }^{10} \mathrm{https}: / / 9 g a g . c o m / g a g / a Z L K 160$ (accessed on 24/05/2019)

${ }^{11}$ https://9gag.com/gag/aj8j1Zp (accessed on 24/05/2019) 
popularity. This video has a comical character and political function and displays Theresa May, how she "sings" a popular rep song by rep musicians Still Dre. The text of the song is changed so that satirically talks about the politics of Theresa May on the issue of Brexit. Just "singing" of the Prime Minister of Great Britain is actually a combination of certain words allocated from her television statements. It is characterized by exceptional creativity and commitment in creating, as well as concealed criticism and disagreement with this policy, presented in the form of globally known song.

Latest meme on this list is another gif of neutral context and entertainment features with the 9030 positive ratings entitled "Kid makes two clutch free throws to take the lead with 2 seconds left ${ }^{12 \text {. }}$. Gif shows basketball game off children in China where the boy scores two free throws and thus brings his team to clear advantage of one point, two seconds before the end of the match. However, after that, the boy from the opponent's scores, hitting from the entire length of the field and with this hit team inverts result and wins the match. The credit for the popularity of this gif owes to that what shows this incredibly rare moment in basketball, that even children were playing, which makes a move even more amazing. A unique role is played by the text gif, alleging viewers to misleading, bringing meme unexpected turn.

It is very interesting that none of the five popular gifs are in the form of a photograph or image, which means that photos are the most numerous, but they are not the highest quality, that is, most attractive memes. The impression is that memes will increasingly be created in the form of moving images, due to higher information capacity. Also, although they account for just over $22 \%$ of the analyzed memes, those who have a neutral character make up even $80 \%$ of the first 5 most popular. Such gifs can show more interesting and complex ideas and events from entertainment one, which are often too simple and does not stand out individually in the mass of the same. The neutral ones are mostly fun, but they can be political and informative. Common to all these memes is that because they are dealing with well-known phenomena such as bullying, baptism, pregnancy, cats, basketball or global problems of Brexit and that this kind of parodying and putting in an extraordinary situation of phenomena common to all people in the world, makes them popular. Withdrawal from the scope of the expected (basket score from a half-court, confronting the bully) and the relocation of context (Theresa May as a rapper, cat on ultrasound) is very important because it contributes to our memory and expansion of memes over the Internet. In the end, the simplicity of form and text (with the exception of a video about Theresa May) make these memes available to all users, for quick understanding without the need for deeper analysis, corresponds to a rapid visual society of Internet. Therefore, out of all presented, it may be determined that the fourth hypothesis which claims that the most popular memes are parodying popular series and movie form, has not been confirmed. Even though movies and series very popular, themes that deal with the most popular memes arise from more famous and ever-present, a daily phenomenon's of a global society.

\footnotetext{
${ }^{12} \mathrm{https} / / / 9$ gag.com/gag/aE2bVoe (accessed on 24/05/2019)
} 
As the first, second and third hypothesis are confirmed, while the fourth is not, it can be concluded Internet Memes appear in the form of photo or image, humorous character in function of entertainment are the most common, but this is not the case when it comes to most popular memes. Photo, that is picture memes appear in the highest percentage, as well as comical and those in the function of entertainment, but popularity is not based on the context of the popular series and movies, but rather the context of everyday human society. It should be noted that, according to the analysis of those who were the most popular, there is a high probability that in the future, image or photo memes will appear in all less and less and they will be replaced by memes with moving pictures. Also, it is possible that shaping in a comical way memes could be replaced by a neutral one. The only characteristic that can be assumed to remain constant is that memes will mostly in the coming period be used as a means of entertainment.

\section{Concluding observations}

The phenomenon of Internet memes is very widespread in the visual society of the 21st century. With their appealing visual form and simplicity, a well-known structure, they are ideally suited to new-made habits of the public social network, which is prone to receive information by looking. Memes are appearing in several forms, were created in different contexts and their functions, in addition to entertainment can also be informative, and because of the growing power of visual communication, they are also used in political and marketing communication. According to the survey, the most commonly appearing is in the form of pictures or photographs, they have comical character and they are in a function of entertainment. However, even though these are the most common cases, the most popular memes do not share all the characteristics of the most numerous, but they are largely designed in the form of moving pictures (gif or video) and with neutral character. The only constant feature of the most numerous memes and most popular, is that they are mostly aimed to entertain. Relative to popularity, it is common that every meme communicates about and relating to the standard of everyday things common to all cultures around the world, which is why every user of the global Internet society can identify with them. Creativity and unexpectedness are essential in popularity and spreading of memes and it is those characteristics that determine memes virality and "lifetime".

Given the fact that the most popular memes are different from most numerous in form and character, it can be assumed that it will, with the development of higher speed of the Internet and software for processing of memes, those who are in the form of GIF or video, suppress the dominance of image and photo memes. Those who use moving images to display their messages can convey more information and message varieties. Also, such memes will not have to rely on the comedy for the sake of popularity, but with neutral context and creative contextualizing the presented one will attract attention to himself. 
The significance of the work is that it shows the phenomenon of memes, their characteristics and the different ways in which these can be classified. Also, thanks to the research, are determined the most common characteristics and most popular types of memes, are revealed differences between the most popular and the most numerous among them, leading to the possibility of predicting the future of development of memes. The disadvantages of research are that are analyzed a relatively small number of memes in a short period of time and only on one website, and that memes are analyzed by only four variables.

The work could serve as a base for more extensive and more sophisticated research, which will analyze more parameters of characteristic of memes, a larger number of them and on more websites, or with these work we could, as a basis, develop a longitudinal study that will be aimed for monitoring the phenomenon of Internet memes through time. The most interesting thing would be to determine whether will ever the function of entertainment stop to be a dominant role of memes in the global visual society or it will, as this study suggests, this feature of memes remain the only unchangeable constant.

\section{References}

Baldwin, J. Roberts, L. (2006). Visual Communication: From Theory to Practice. AVA Publishing. ISBN 10: 2940373094

Blackmore, S. (1999). The Meme Machine. Oxford University Press: Oxford

Börzsei, L. (2013). Makes a Meme Instead: A Concise History of Internet Memes. New Media Studies Magazine Iss. 7 http://works.bepress.com/linda_borzsei/2/

Bury, B. (2016). Creative Use of Internet Memes in Advertising. World Scientific News 57

Chagas, V, Freire, F, Rios, D, Magalhães, D. (2019). Political memes and the politics of memes: A methodological proposal for content analysis of online political memes. First Monday. 24. 10.5210/fm.v24i2.7264.

Dawkins, R. (2006). The Selfish Gene: 30th Anniversary Edition, 3rd ed. Oxford University Press: Oxford, UK

Díaz, C. (2013). Defining and characterizing the concept of Internet Meme. CES Psicología, 6(2), 82-104. http://www.scielo.org.co/scielo.php?script=sci_arttext\&pid=S201130802013000200007\&lng=en\&tlng=en.

Hackley,C.(2007).MarketingPsychologyandtheHiddenPersuadershttp://www.thepsychologist. org.uk/archive/archive_home.cfm?volumeID=20\&editionID=150\&ArticleID=1228. The Psychologist. 20. 488-491.

Huntington, H. (2017). The Affest and Effect of Internet memes: Asscendingand Influence of Online User-generated Political Discourse as Media, Colorado State University: Fort Collins, Colorado, https://mountainscholar.org/bitstream/handle/10217/183936/ Huntington_colostate_0053A_14303.pdf?sequence=1

Juza, M. (2013.) Internet memes - creation, distribution, social meaning u Media Studies .2013, Vol. 55, p1-15. 15p. http://studiamedioznawcze.pl/Numery/2013_4_55/juza-en.pdf 
Kulkarni, A. (2017). Internet meme and Political Discourse: A study on the impact of internet meme as a tool in communicating political satire. Journal of Content, Community \& Communication. Amity School of Communication Vol. 6 Year 3, Amity University, Madhya Pradesh [ISSN: 2456-9011 (Online)]

Luhmann, N. (1975). Soziologische Aufklärung, Bd. 2, Opladen

Mekluan, M, (2012.), Elektronski mediji i kraj kulture pismenosti, Karpos: Beograd

Milner, R. M. (2012). “The World Made Meme: Discourse and Identity in Participatory Media.” PhD diss., University of Kansas. https://kuscholarworks.ku.edu/bitstream/ handle/1808/10256/Milner_ku_0099D_12255_DATA_1.pdf? sequence=1.

Murray N. Manrai A.. Manrai, L. (2014). Memes, memetics and marketing, [in:] Louis Moutinho, Enrique Bigné, and Ajay K. Manrai (Eds.), The Routledge Companion to the Future of Marketing, New York, NY: Routledge, pp. 331-347.

Obradovic, N., Milosavljevic, I., \& Vujovic, M. (2017). Instagram as a New Platform for Media Content - Students' Stance. In The International Scientific Conference eLearning and Software for Education (Vol. 1, p. 181). "Carol I" National Defence University.

Oklhoma state universuty. (2016). Learnin styles. Oklahoma 4-H Volunteer Development Series. Vol.115 http://4h.okstate.edu/literature-links/lit-online/others/volunteer/4H. VOL.115\%20Learning\%20Styles_08.pdf/

Olsen, D. (2018). How memes are being weaponized for political propaganda. U https:// www.salon.com/2018/02/24/how-memes-are-being-weaponized-for-politicalpropaganda/

Piñeiro-Otero, Teresa \& Martínez-Rolán, Xabier. (2016). The use of memes in the discourse of political parties on Twitter: Analysing the 2015 state of the nation debate. Communication \& Society. 29. 145-159. 10.15581/003.29.1.145-159.

Plevriti, V. (2014). Satirical User-Generated Memes as an Effective Source of Political Criticism, Extending Debate and Enhancing Civic Engagement. Centre for Cultural Policy Studies: The University of Warwick. URL: https://pdfs. semanticscholar.org/d0d9/474318b12c8ef519951f1ee93b27a655092b.pdf?_ $\mathrm{ga}=2.65908398 .1008841494 .1559318403-1636171915.1559318403$

Radovanović-Šarenac, D. (2012). Specifičnosti online novinarstva. Politeia, 2(3), 257-263.

Ross, A. Rivers, D. J. (2017). Internet Memes as Polyvocal Political Participation. The Presidency and Social Media Discourse, Disruption, and Digital Democracy in the 2016 Presidential Election. Ruotlege. 285-308

Shifman, L. (2014). Memes in Digital Culture, The MIT Press Essential Knowledge series: Massatusetts

Sturken, M, Cartwright, L, (2001). Practices of Looknig: an Introduction to a visual culture; New York : Oxford University Press

Šešum, J. (2011). Internet mimovi - aspekti globalnog komuniciranja. CM - časopis za upravljanje komuniciranjem, 6(18), 107-117.

Teh, I. (2012). Characteristics of Memes. URL: https://ivanteh-runningman.blogspot. com/2012/02/characteristics-of-memes.html

Vreg, F. (1991). Demokratsko komuniciranje. Narodna i univerzitetska biblioteka BiH, Fakultet Političkih Nauka: Sarajevo 


\section{Website}

BBC. "Grumpy Cat internet legend dies". Accesed on 18/05/2019. https://www.bbc.com/ news/world-us-canada-48308638

CNN. "Grumpy Cat, the grouchy-faced furball that launched a thousand memes, is dead." Accesed on 18/05/2019. https://edition.cnn.com/2019/05/17/celebrities/grumpycat-dead-intl-scli/index.html

9gag. "This is how to stop bullying." Accessed on 24/05/2019. https://9gag.com/gag/arG03wV

9gag. "Expecting mother getting an ultrasound." Accessed on 24/05/2019 https://9gag. com/gag/aVY8o4M

9gag. "Stick one of these in your pocket, then go to get baptized." Accessed on 24/05/2019. https://9gag.com/gag/aZLK160

9gag. "Still D.R.E mashup ft Theresa May.” Accessed on 24/05/2019. https://9gag.com/gag/ aj8j1Zp

9gag. "Still D.R.E mashup ft Theresa May." Accessed on 24/05/2019. https://9gag.com/gag/ aE2bVoe

\section{FENOMEN INTERNET MIMOVA KAO MANIFESTACIJA KOMUNIKACIJE DRUŠTVA VIZUELNOSTI - ISTRAŽIVANJE O NAJPOPULARNIJIM I NAJBROJNIJIM VRSTAMA}

Sažetak: društvo 21. veka je društvo vizuelne komunikacije koja se u najvećoj meri odvija putem interneta. Od mnogih formi vizuelnog izražavanja na internetu među najrasprostranjenijim i najizražajnijim su i mimovi. Internet mimovi su najčešće video i fotografski sadržaji na internetu, koji prenose određenu (najčešće duhovitu) poruku a čiji su kodovi i značenje dobro utemeljeni u globalnoj kulturi.

Cilj rada je definiše, objasni, istorijski prikaže, klasifikuje i ukaže na funkcije internet mimova, kao i da uoči koja vrsta mimova je najčešša i/ili najpopularnija i koje su njene karakteristike. Osnovna hipoteza istraživanja glasi: najčešće vrste internet mimova pojavljuju se u formi fotografije, humorističkog su karaktera u funkciji zabave i oni su najpopularnije jer parodiraju popularne serijske i filmske forme. Istraživanje je vršeno kvantitativnom i kvalitativnom analizom sadržaja 150 najpopularnijih mimova u vremenskom periodu od 22. do 24. maja 2019. Na sajtu 9gag.com. Prikupljeni podaci klasifikovani su i komparirani statističkom analizom u programu SPSS 20.0. Rezultati ukazuju da u najbrojniji medu popularnim mimovima oni u formi fotografije ili slike, da su najčešće komičnog karaktara i u funkciji zabave, a da su najpopularniji medu njima oni koji se bave fenomenima i pojavama zajedničkim za sve ljude. Takođe uočena je veća popularnost mimova u formi pokretnih slika i u neutralnom kontekstu u odnosu na one koji su najbrojniji ( $u$ formi slike ili fotografije i u komičnom kotekstu). Jedina zajednička i nepromenjljiva karakteristika i navećeg broja mimova kao i onih koji su najpopularniiji je da su u funkciji zabave.

Ključne reči: internet mimovi, slike, vizuelno društvo, video, komunikacija 